\title{
Case for continuing community NIV and CPAP during the COVID-19 epidemic
}

\author{
Jillian G Baker, ${ }^{1,2}$ Milind Sovani
}

Dear Editor,

Recent clinical guidelines regarding the use of home non-invasive ventilation (NIV) and continuous positive airway pressure (CPAP) during the COVID-19 epidemic have tried to balance the risks of stopping NIV or CPAP against the unknown potential risk of increased aerosol-related transmission to family and carers. ${ }^{12}$ We read with interest views put forward by Barker $e t$ $a l^{3}$ but feel that wider aspects need consideration, and for NIV and CPAP separately.

NIV use: NIV is primarily used for those with previous, or at risk from, hypercapnic respiratory failure (neuromuscular disorders, chest wall deformity, obesity or underlying lung disease, for example, COPD). Stopping home NIV risks the return of symptoms (lethargy, headache, dyspnoea and confusion), increased patient and family anxiety and precipitating life-threatening acute hypercapnia, which is likely to result in hospital admission, patient exposure to COVID-19 and other infections, as well as causing increased (and preventable) pressure on ventilator beds. Home NIV patients often have limited mobility or are housebound. They have been advised to self-isolate and, in our experience, most patients are following the advice. There is therefore a higher risk of a carer to patient transmission. NIV does generate droplets, but using a non-vented mask with a viral filter reduces the spread significantly. ${ }^{4}$ We however recognise that should patient get infected then there is a risk to carers.

Continuing home NIV, with increased family member care, backed up with remote assistance from specialist carers, is an option. When direct carer input cannot be avoided, simple measures, for example, hand washing and opening windows and doors before a visit to reduce airborne viral load (a single change of room air reduces viral load by $63 \%$, five changes to less than $1 \%,{ }^{5}$ ) and personal protective

\footnotetext{
${ }^{1}$ School of Life Sciences, University of Nottingham, Nottingham, UK

${ }^{2}$ Department of Respiratory Medicine, Nottingham University Hospitals NHS Trust, Nottingham, UK
}

Correspondence to Professor Jillian G Baker, School of Life Sciences, University of Nottingham, Nottingham NG7 2RD, UK; Jillian.Baker@nottingham.ac.uk equipment will be required. For patients in care facilities or requiring hospital admission, a side room and pre-emptive change of mask and circuit with a viral filter in combination with precautions listed above should minimise risk.

CPAP use: CPAP is primarily used for those with obstructive sleep apnoea (OSA). While CPAP treatment improves symptoms (sleepiness, headaches, concentration, memory and mood) it is rarely life-preserving. However, stopping home CPAP may cause a deterioration in physical and mental health, in addition to social distancing and home isolation. Increased sleepiness will affect driving and safety critical jobs and work productivity may fall. The return of snoring may reduce family members' sleep, affecting household temperaments and compounding frustration from being confined to the home.

Stopping CPAP for the entire epidemic duration cannot be recommended, especially for key workers, those with safetycritical jobs and those with increased workload during the pandemic. If a CPAPuser develops symptoms (or has asymptomatic proven COVID-19) then self-isolation and stopping CPAP for 2 weeks might be sensible. To minimise any in-hospital transmission, we are asking patients not to bring home CPAPs, masks or equipment into hospital (assuming contamination) and are not treating straightforward OSA with CPAP in hospital during the epidemic. Patients with decompensated obesity hypoventilation or COPD/OSA overlap will be provided with a non-vented mask, viral filter and vented circuit in a side room with a hospital CPAP machine.

Thus, while we fully accept there is an unknown, potentially increased, risk of viral transmission for other household members and carers, should the NIV-user or CPAPuser be COVID-19 positive, we believe that blanket advice to withhold home NIV and CPAP for all users, for what may be a substantial period (maybe 12 weeks or even longer), will cause significant, and measurable, patient harm.

Contributors JGB and MS are the sole authors.

Funding The authors have not declared a specific grant for this research from any funding agency in the public, commercial or not-for-profit sectors.

Competing interests JGB provides molecular pharmacology advice for CuraSen Therapeutics. MS has received speaking fees from Chiesi, StraZeneca and Radiometer, received assistance form ResMed towards attending ERS, received funding from RESMED, Breas and Philips Respironics towards organising a Sleep and Ventilation course and received a $£ 45,000$ Research Grant and four Transcutaneous carbon dioxide monitors (TCM5) as well as consumables from Radiometer towards a multicentre study.

Patient consent for publication Not required.

Provenance and peer review Commissioned; internally peer reviewed.

This article is made freely available for use in accordance with BMJ's website terms and conditions for the duration of the covid-19 pandemic or until otherwise determined by BMJ. You may use, download and print the article for any lawful, non-commercial purpose (including text and data mining) provided that all copyright notices and trade marks are retained.

(c) Author(s) (or their employer(s)) 2020. No commercial re-use. See rights and permissions. Published by BMJ.

Check for updates

To cite Baker JG, Sovani M. Thorax 2020;75:368.

Published Online First 9 April 2020

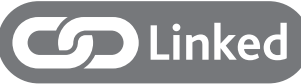

- http://dx.doi.org/10.1136/thoraxjnl-2020-214890

Thorax 2020;75:368.

doi:10.1136/thoraxjnl-2020-214913

\section{REFERENCES}

1 Guidance regarding coronavirus (COVID-19) and obstructive sleep apnoea (OSA): for people who routinely use continuous positive airway pressure (CPAP), their families and health care workers. Available: https://www.brit-thoracic.org.uk/media/455098/ osa-alliance-cpap-covid-19-advice-20-3-20-v10.pdf [Accessed 20 Mar 2020].

2 NHS. Clinical guide for the use of acute non-invasive ventilation in adult patients hospitalised with suspected or confirmed coronavirus during the coronavirus pandemic Available: https://www.england.nhs.uk/coronavirus/wpcontent/uploads/sites/52/2020/03/clincial-guide-acuteniv-ventilation-v1-19-march-2020.pdf

3 Barker J, Oyefeso O, Koeckerling D, et al. COVID-19: community CPAP and NIV should be stopped unless medically necessary to support life. Thorax 2020;75:367

4 Simonds AK, Hanak A, Chatwin M, et al. Evaluation of droplet dispersion during non-invasive ventilation, oxygen therapy, nebuliser treatment and chest physiotherapy in clinical practice: implications for management of pandemic influenza and other airborne infections. Health Technol Assess 2010;14:131-72.

5 Public Health England. COVID-19: guidance for infection prevention and control in healthcare settings. version 1.0. Available: https://assets.publishing.service.gov. uk/government/uploads/system/uploads/attachment data/file/872745/Infection_prevention_and_control_ guidance_for_pandemic_coronavirus.pdf 